\title{
Retrospective analysis of epiphyte assemblages in relation to seagrass loss in a eutrophic coastal embayment
}

\author{
M. L. Cambridge ${ }^{1, *}$, J. R. How ${ }^{2}$, P. S. Lavery ${ }^{2}$, M. A. Vanderklift ${ }^{3}$ \\ ${ }^{1}$ School of Plant Biology, The University of Western Australia, 35 Stirling Highway, Crawley, Western Australia 6009, \\ Australia \\ ${ }^{2}$ Centre for Ecosystem Management, Edith Cowan University, Joondalup, Western Australia 6027, Australia \\ ${ }^{3}$ CSIRO Marine Research, Private Bag No. 5, Wembley, Western Australia 6913, Australia
}

\begin{abstract}
This is a retrospective study of shifts in species composition of epiphytic macroalgae that occurred during a period of seagrass loss in Cockburn Sound, Western Australia. Detailed analysis of data on relative abundances of 108 epiphytic taxa collected over 2 yr from 27 widely dispersed sites around Cockburn Sound showed differences in epiphyte composition between sites with loss of seagrasses (Loss sites) and those with no loss in the the long-term (No Loss sites). Future seagrass losses, however, were not predicted by shifts in species composition. Most species were rare and varied with season of sampling. Hence, varying assemblages of species contributed to differences on each sampling occasion. Only 6 of the 108 species were strong, consistent contributors to differences between Loss and No Loss sites (Sphacelaria sp., Laurencia sp., Enteromorpha intestinalis, E. prolifera, Ulva lactuca, Acrochaetium sp.) and could be considered as 'indicator species'. Only 2 species (Sphacelaria sp. and Laurencia sp.) were present consistently in high abundances at No Loss sites. Foliose green algae (Ulva sp., Enteromorpha spp.), commonly considered to signal eutrophication, were found consistently in higher abundances at Loss sites. Shifts in epiphyte species composition correlated with patterns of nutrient loading and seagrass decline, in addition to the increases in biomass reported earlier, but did not predict future seagrass loss.
\end{abstract}

KEY WORDS: Seagrass - Epiphytes · Eutrophication - Species composition · Posidonia $\cdot$ Western Australia Resale or republication not permitted without written consent of the publisher

\section{INTRODUCTION}

The common wisdom on the effect of nutrients on seagrass is that increasing nutrient supply results in the overgrowth of seagrasses by epiphytic macroalgae, and in extreme cases, the death of the seagrasses. Fundamental in developing this paradigm have been some earlier studies (e.g. Orth \& Moore 1983, Cambridge et al. 1986) that have been cited regularly in the literature and repeatedly 'confirmed' with statements that nutrient enrichment stimulates the growth of epiphytic algae (e.g. Wear et al. 1999, Moore \& Wetzel 2000). Observational and experimental studies have indeed reported increases in epiphyte biomass in response to nutrient loading (e.g. Silberstein et al. 1986, Tomasako \& Lapointe 1991, Neckles et al. 1994), and this increase in epiphyte biomass has been emphasised in the cause-effect pathway of nutrient enrichment leading to seagrass loss (Cambridge et al. 1986, Silberstein et al. 1986, Frankovich \& Fourqurean 1997). However, Cambridge et al. (1986) also described rapid changes in species composition associated with heavy epiphyte fouling and seagrass decline.

Since these early studies, shifts in epiphyte species composition and increases in biomass under increased nutrient loading have been observed (Coleman \& Burkholder 1994, Cebrian et al. 1999, Frankovich \& Fourqurean 1997, Hauxwell et al. 2001). Epiphytic 
macroalgae encompass a range of sizes and morphologies, including foliose, encrusting and filamentous forms, and may be erect or creeping, as well as calcareous. Consequently, shifts in composition and associated morphologies have significant implications for the light-attenuating capacity of the epiphytic layer, even without significant increases in biomass (Brush \& Nixon 2002, Brun et al. 2003, Drake et al. 2003, Frankovich \& Zieman 2005). Given that shifts in composition can result from nutrient enrichment, and that these shifts may have major effects on light available to the host seagrass, even without significant increases in biomass, then compositional changes in epiphyte assemblages may also be implicated in seagrass decline and could perhaps serve as an early warning signal of eutrophication. The significant developments in multivariate analysis prompted us to perform a retrospective analysis on compositional changes in seagrass epiphytes associated with seagrass decline in a eutrophicated marine system.

More than $70 \%$ of the seagrass cover was lost in Cockburn Sound, a marine embayment on the Western Australian coast, during the early 1970s (Cambridge \& McComb 1984). A marked increase in N-loading from industrial sources coincided with a period of major seagrass loss, providing circumstantial evidence for a link between increased nitrogen loads, increased epiphyte biomass and deterioration of seagrass (Cambridge et al. 1986). Soon after the loss of seagrass began, epiphytic algae were sampled on Posidonia sp. at sites around Cockburn Sound. A recent project to re-map the sequence of seagrass loss using digital techniques (Kendrick et al. 2002) provided an opportunity to test whether patterns in the species composition of epiphytic macroalgae recorded during the early stages of seagrass loss coincided with subsequent patterns of seagrass loss. If this were the case, it would suggest that there is a potential for testing whether compositional shifts in epiphytic macroalgae were associated with or predicted seagrass decline. Because the ecological significance of shifts in composition may be related to shifts in morphological composition of the algal assemblages, we analysed the assemblages of epiphytic macroalgae on Posidonia for differences in both species and functional group compositions. Assemblages were compared among all sites that had been monitored during the early 1970s, and included sites where seagrass had already begun dying and was subsequently lost, and sites where seagrass persisted well beyond the phase of major dieback, often to the present day. As sampling had occurred on 5 occasions during 1970 to 1972 , we were able to track changes in epiphyte composition where seagrass depletion was in progress, for comparison with sites where seagrass meadows persisted.

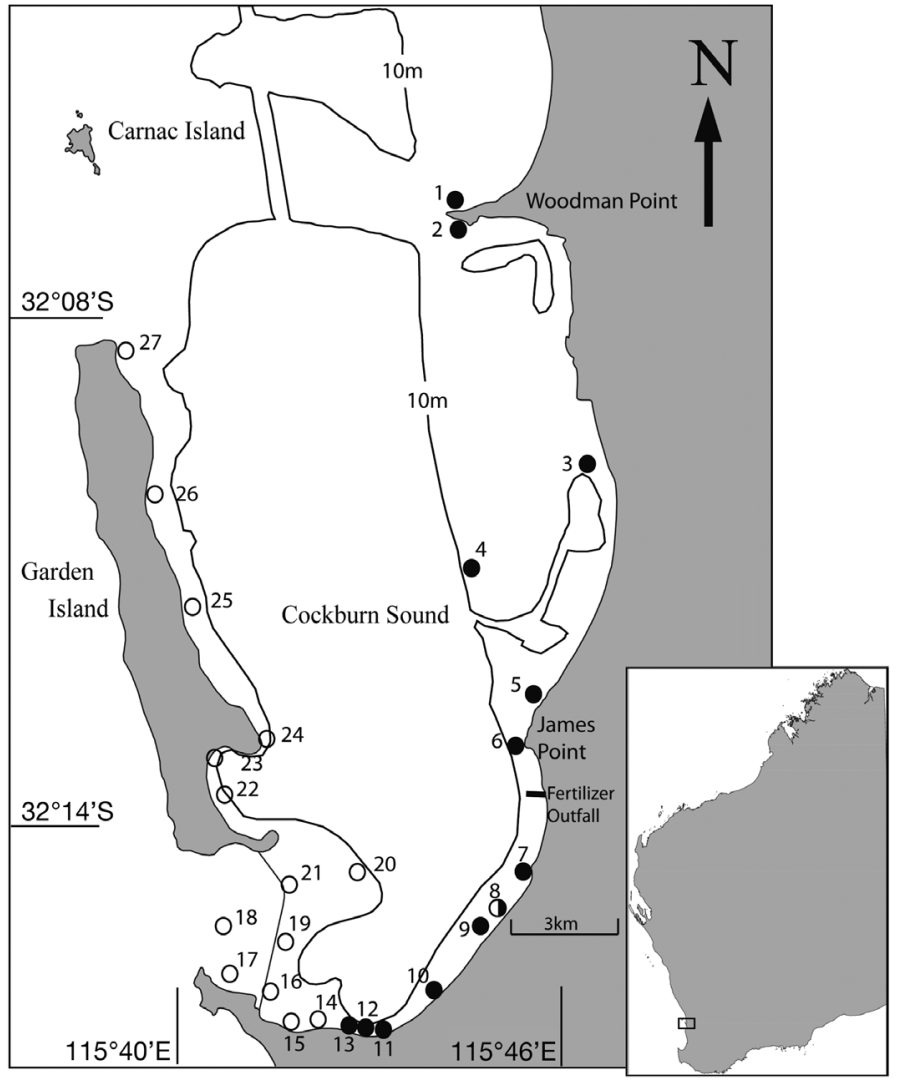

Fig. 1. Location of sample sites in Cockburn Sound. •: Loss sites (where seagrass dieback was evident at the time of sampling); O: No Loss sites (where seagrass appeared healthy during sampling and persisted into the future). O: (Site 8, Rockingham Light): progressive change from No Loss to Loss over the 2 yr period of sampling, at the end of which seagrass began to show signs of deterioration and epiphytic algal composition became more similar to Loss sites

\section{METHODS}

Site description. The study was carried out in Cockburn Sound $\left(32^{\circ} \mathrm{S}, 115^{\circ} \mathrm{E}\right)$, a microtidal semi-enclosed marine embayment near Perth on the Western Australian coast (Fig. 1). Cockburn Sound consists of a central basin approximately $15 \mathrm{~km}$ long and $6 \mathrm{~km}$ wide with a mean depth of about $20 \mathrm{~m}$, sheltered from ocean waves by Garden Island along the length of the western boundary. The basin is bordered by sand platforms once vegetated by seagrasses (predominantly Posidonia sinuosa Cambridge \& Kuo and P. australis Hook. $f$.) to depths of 8 to $10 \mathrm{~m}$, with minor occurrences of other species (Cambridge 1975, Cambridge \& Kuo 1979, Kendrick et al. 2002). Shallow sand sills 3 to $8 \mathrm{~m}$ in depth lie across the northern and southern ends of the sound, and there is a gently sloping shelf on the north eastern margin. Construction of a solid, rock-fill causeway from 1971 to 1974, linking the mainland with Gar- 
den Island, partially blocked the southern entrance of Cockburn Sound, allowing only limited exchange with adjacent waters through 2 gaps spanned by bridges.

Industrial development began on the central eastern shore in 1955, but there were no major losses of seagrass until 1969, soon after discharge of nitrogen-rich effluent from a fertilizer plant commenced south of James Point. Effluent was discharged into beach drains adjacent to seagrass meadows on the sand platforms bordering the sound. Depletion of seagrass was rapid, with more than $70 \%$ lost within a decade (Cambridge \& McComb 1984).

Cockburn Sound has restricted exchange with adjacent coastal waters, which, combined with patterns of internal circulation, affects both dispersal of industrial effluents from point sources on the eastern shore and replacement rates of the whole water mass. At the whole-basin scale, hydrodynamics are primarily influenced by wind stress and density gradients (Mills \& D'Adamo 1995). At smaller scales, earlier studies modelled a series of gyres forced by typical wind patterns (Steedman \& Craig 1983); the largest gyre occupied most of the eastern half of the sound, with 2 small gyres in the southeast (Mangles Bay) and northwest. These modelled flow patterns were broadly validated by comparison with the transport and dispersal of cadmium, which acted as a tracer for effluent released from James Point (Rosman et al. 1980).

Data collection. Epiphyte assemblages on Posidonia sinuosa were sampled at 27 widely dispersed sites in Cockburn Sound over 2 yr (Fig. 1), including locations where (1) seagrass was already showing signs of deterioration and where losses occurred subsequently during the 1970s, designated as 'Loss' for our analyses, and (2) seagrass was present and persisted well into the future, designated as 'No Loss'. Sampling coincided with construction of the causeway.

There were 5 sampling occasions. A pilot study was undertaken in August 1970, followed by comprehensive sampling in December 1970, May 1971, May 1972 and October 1972. Of the 27 sites sampled, only 4 were sampled on all 5 occasions (Table 1). At one of these sites, Rockingham Light (Site 8, Fig. 1), seagrass meadows showed no signs of loss at the beginning of the study, but losses occurred during the period of sampling. There were still enough remnant patches to sample in 1972 but the entire meadow along the southeastern shore had been lost by 1981. This site was reclassified accordingly from No Loss to Loss (see 'Statistical analyses', below).

At each site, Posidonia sinuosa leaves were sampled from permanently marked quadrats along a transect. Up to 15 quadrats $\left(0.01 \mathrm{~m}^{2}\right)$ were sampled at each site. All leaves were clipped approximately $1 \mathrm{~cm}$ above the leaf bases, which allowed leaves to regrow. Samples were bagged and preserved in $4 \%$ formalin in seawater.

In the laboratory, 12 long leaves (40 to $50 \mathrm{~cm}$ long, estimated to be 60 to $120 \mathrm{~d}$ old) with well-developed epiphyte cover were haphazardly selected from each quadrat sample and both sides of the leaves were examined using a dissecting microscope at 10 to $20 \times$ magnification. The number of leaves out of 12 on which a taxon occurred was recorded for all quadrats at each site, and converted to relative abundance on a scale of 0 to 1 . Epiphytic algae (macroalgae and multicellular cyanobacteria) were identified to species where possible. Some taxa were only recognisable to the genus level as they were still in the juvenile phase. In the case of cyanobacteria, some taxa were categorised in morphological groups, because the taxonomy was poorly known. All taxa recorded were 
included in a permanent reference collection housed at the Western Australia Herbarium, Perth, with preserved specimens mounted on microscope slides in 'Karo' corn syrup with $1 \%$ phenol.

Each species identified was assigned to an algal functional group (filamentous, foliose, saccate, corticated filamentous, corticated foliose, blue-green algae, encrusting, articulated calcareous or coralline, or leathery), adapted for Western Australian algae from the functional group model described in Steneck \& Dethier (1994) and Phillips et al. (1997).

Statistical analyses. Each site was assigned to one of 2 categories (Fig. 1), either No Loss (site with continual seagrass cover since the 1970s) or Loss (site where seagrass died during the early 1970s, with no subsequent recovery), based on the time-course of seagrass loss (Kendrick et. al. 2002). An exception was made in the case of Rockingham Light (Site 8), which was sampled on all 5 occasions (Table 1) and where seagrass loss was in progress during the sampling. Continuous seagrass meadow was evident in aerial photographs from 1967 to 1972 , but was clearly reduced to remnants in the period from 1972 to 1981 . This site was therefore classed into different categories depending on the sampling date, viz. as a No Loss site for samples taken prior to 1972, but a Loss site for the 2 remaining sampling occasions in 1972.

Analyses focussed on differences between Loss and No Loss groups in community composition at the species assemblage and functional group levels, with sites as the units of observation. We explored patterns and tested for differences using nonparametric multivariate statistical methods. All analyses were performed using PRIMER software (Clarke \& Warwick 2001). We conducted separate analyses for each sampling occasion, and a set of analyses in which all sampling occasions were included (for this latter analysis, all sampling occasions for each site were included). To examine the significance of patterns in species composition between Loss and No Loss sites, we conducted analyses of similarities (ANOSIM) based on Bray and Curtis dissimilarity matrices. We used non-metric multidimensional scaling (n-MDS) to construct 2-dimensional ordinations of all sites based on BrayCurtis dissimilarity values calculated from untransformed proportion data.

To examine the epiphytic macroalgal taxa that contributed most strongly to dissimilarities between samples from different regions and/or sampling periods, we used the SIMPER method described by Clarke (1993). We employed the average contribution of each taxon to the overall dissimilarity between sets of samples $i$, and the standard deviation of this contribution $\mathrm{SD}(i)$. We used the ratio of mean to SD to evaluate the contribution of each taxon to the dissimilarity between pairs of samples. We used as an arbitrarily defined cut-off point a mean to $\mathrm{SD}$ ratio of 2 , so that the mean contribution was higher than the variation. Species that contributed $>3 \%$ to the dissimilarity on any of the 5 sampling occasions were examined further. To assess trends, we plotted the proportions of species that contributed $>3 \%$ to the dissimilarity on at least 3 of the 5 sampling occasions.

\section{RESULTS}

\section{Differences in community composition: species assemblage analyses}

ANOSIM tests yielded significant differences in species composition between Loss and No Loss sites for all 5 sampling occasions (Fig. 2). The Clarke $R$ statistic was relatively high for the earlier sampling occasions (0.57 to 0.82, August 1970 to May 1971), which supports the conclusion that meaningful differences in species composition were present between Loss and No Loss sites. However, values were lower in 1972 and across all times (0.36), indicating less dissimilarity.

The differences in species composition detected by ANOSIM were reflected in the patterns displayed by the ordinations. There was little or no overlap of Loss and No Loss locations in any ordination (Fig. 3). The stress values for each of the ordinations were low, indicating that theses were good representations of the underlying dissimilarity values.

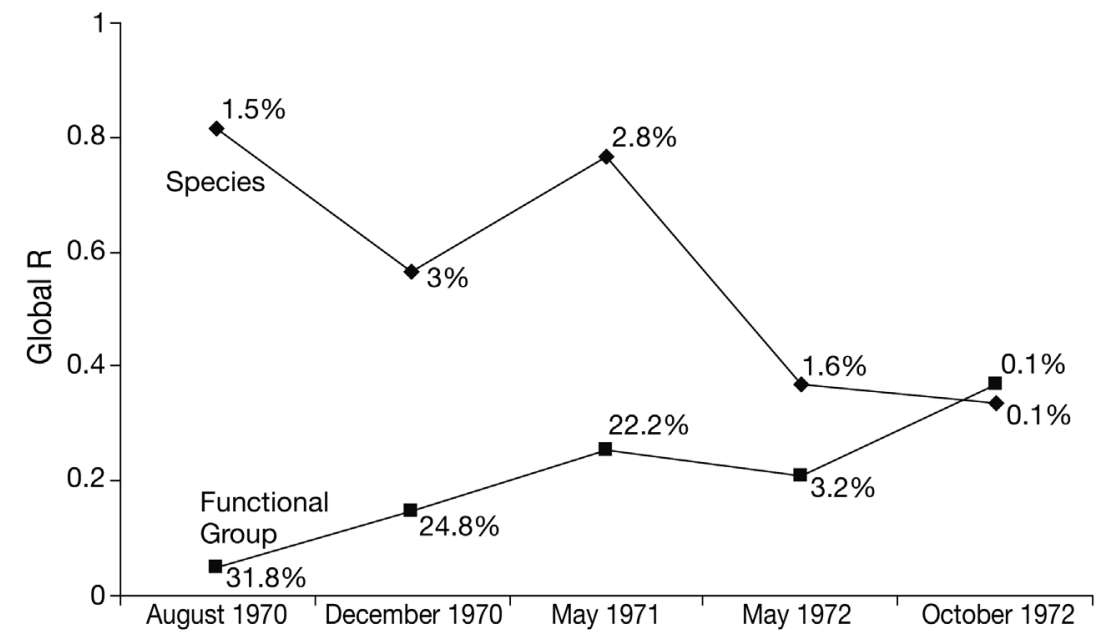

Fig. 2. ANOSIM statistics (Clarke's $R$ statistic [Global R] and significance) for differences in composition at species assemblage and functional group levels between Loss and No Loss sites for all sampling occasions 


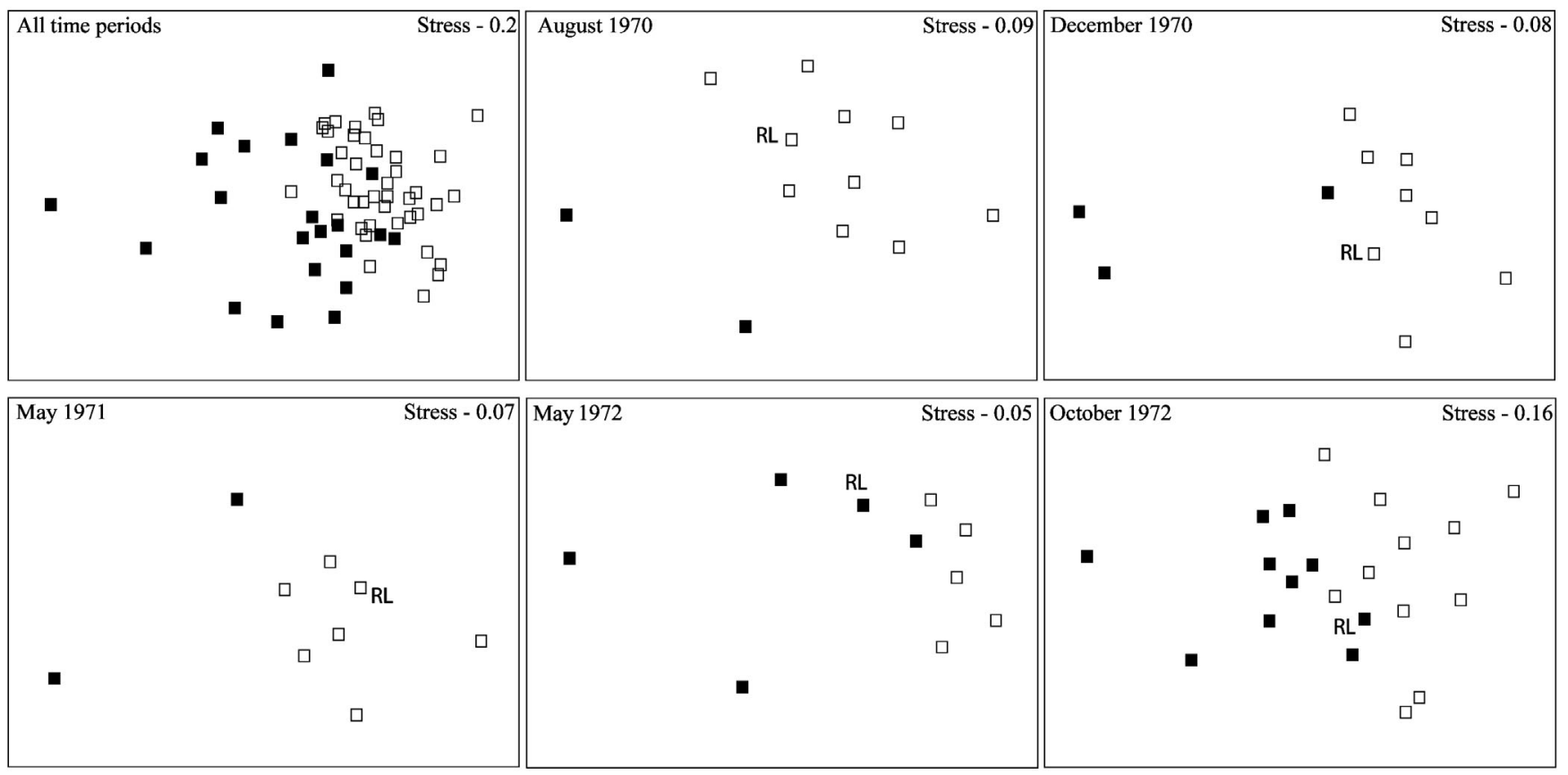

Fig. 3. n-MDS (multi-dimensional scaling ordination) of epiphyte species assemblages on Posidonia sinuosa for all 5 sampling occasions and all times combined. $\square$ : sites where seagrass loss occurred; $\square$ : No Loss sites. Note the changes in position of Rockingham Light (RL, Site 8) which was sampled throughout the study period and began to show seagrass loss late in 1971. This site was reclassified accordingly, from a No Loss to a Loss site in 1972, epiphytic algal composition became more similar to Loss sites

One of the sites that was sampled on all 5 occasions (Rockingham Light, Site 8) began to show progressive seagrass loss, and was reclassified accordingly from a No Loss site in 1970 to 1971 to a Loss site in 1972. The epiphytic algal composition became more similar to those sites that had already lost seagrass. This change in similarity is evident in the n-MDS plots (see RL in Fig. 3).

\section{Species contributing to differences}

For each sampling occasion, SIMPER analysis showed that a range of taxa contributed to dissimilarity in community composition between Loss and No Loss sites (Table 2). The contribution of individual species was generally less than $7 \%$, indicating that no single species disproportionately contributed to the observed patterns. Many species were rare and did not occur frequently across our sampling regimen. Stronger contributors to dissimilarity (taxa with a mean/SD ratio $>2$ for their contribution to overall dissimilarity between sets of samples; marked with * in Table 2) were often different species on different sampling occasions, reflecting seasonal changes in floral composition. In addition, the contribution of individual species was variable among locations, as indicated by low mean/ $\mathrm{SD}$ ratios (generally $<2$, Table 2 ).
Of a total of 108 taxa recorded during this study, generally with 60 to 70 taxa per sampling period, there were only 6 species that had a contribution of $>3 \%$ to the dissimilarity between the Loss and No Loss sites on all 5 sampling occasions (Sphacelaria sp., Laurencia sp., Enteromorpha intestinalis, E. prolifera, Ulva lactuca, Acrochaetium sp.). These taxa often showed consistent trends in average abundances between Loss and No Loss sites (Fig. 4). Only a few taxa were strong contributors to differences on several dates. Approximately half the taxa contributing to dissimilarity were different for each sampling occasion (Table 2), which in some cases, corresponded to sampling in different seasons, e.g. 4 of the 10 taxa between December 1970 and May 1971. However, there were also differences in taxa contributing to dissimilarity between samples from the same month, but different years (e.g. May 1971 and May 1972).

Two taxa (Sphacelaria sp. and Laurencia sp.) occurred consistently on a higher proportion of leaves at No Loss sites (Fig. 4A,B). Sphacelaria sp. was the strongest contributor to dissimilarity overall, with consistently high average abundance at No Loss sites and lower average abundance at Loss sites (Fig. 4B). Laurencia sp. was not as strong a contributor to dissimilarity, but still contributed consistently to dissimilariy and had consistently higher average abundances at No Loss sites than at Loss sites (Fig. 4B). Enteromorpha 
Table 2. SIMPER analyses showing average relative abundances of taxa at Loss and No Loss sites contributing to average BrayCurtis dissimilarity $\bar{\delta}$ for each sampling period. Species are listed in order of their contribution to Bray-Curtis dissimilarity, with a cut-off when the cumulative \% contribution reached $50 \%$. Taxa which occurred more consistently at either Loss or No Loss sites, and thus were likely to be good contributors to dissimilarity are indicated by * in the Dissimilarity/SD column. Different numbers following generic names indicate different, but unidentified species

\begin{tabular}{|c|c|c|c|c|c|}
\hline Species & $\begin{array}{l}\text { Avg. abundance } \\
\text { Loss sites }\end{array}$ & $\begin{array}{l}\text { Avg. abundance } \\
\text { No loss sites }\end{array}$ & Avg. dissimilarity & $\begin{array}{l}\text { Dissimilarity/ } \\
\text { SD }\end{array}$ & $\begin{array}{c}\text { Contribution } \\
(\%)\end{array}$ \\
\hline \multicolumn{6}{|l|}{ August $1970(\bar{\delta}=62.18)$} \\
\hline Sphacelaria sp. & 0.21 & 0.96 & 7.07 & $2.47^{*}$ & 13.84 \\
\hline Microcystis sp. & 0.63 & 0.02 & 5.76 & $1.41^{*}$ & 11.28 \\
\hline Ceramium 3 & 0.08 & 0.59 & 4.74 & $1.73^{*}$ & 9.27 \\
\hline Polysiphonia 3 & 0.33 & 0.35 & 3.42 & $1.40^{*}$ & 6.69 \\
\hline Polycera sp. & 0.13 & 0.49 & 3.37 & 1.24 & 6.60 \\
\hline Enteromphora compressa & 0.29 & 0.06 & 2.57 & 1.12 & 5.03 \\
\hline \multicolumn{6}{|l|}{ December $1970(\bar{\delta}=59.18)$} \\
\hline Cladophora 3 & 0.71 & 0.06 & 5.12 & $2.06^{*}$ & 8.18 \\
\hline Sphacelaria sp. & 0.31 & 0.80 & 4.05 & $1.51^{*}$ & 6.48 \\
\hline Champia sp. & 0.61 & 0.09 & 4.03 & $1.61^{*}$ & 6.44 \\
\hline Acrochaetium sp. & 0.48 & 0.02 & 3.38 & $2.30^{*}$ & 5.41 \\
\hline Enteromorpha intestinalis & 0.43 & 0.02 & 2.98 & $1.48^{*}$ & 4.77 \\
\hline Cladophora 2 & 0.40 & 0.00 & 2.85 & $1.57^{*}$ & 4.56 \\
\hline Enteromphora compressa & 0.40 & 0.04 & 2.64 & 1.17 & 4.23 \\
\hline Rivularia sp. & 0.29 & 0.48 & 2.41 & 1.23 & 3.86 \\
\hline Ceramium puberulum & 0.15 & 0.37 & 2.38 & 1.37 & 3.81 \\
\hline Laurencia sp. & 0.16 & 0.39 & 2.29 & $2.06^{*}$ & 3.66 \\
\hline \multicolumn{6}{|l|}{ May $1971(\bar{\delta}=53.43)$} \\
\hline Centroceras cinnabarinum & 0.90 & 0.05 & 4.06 & $5.56^{*}$ & 6.90 \\
\hline Enteromorpha (Ulva) lactuca & 0.50 & 0.00 & 2.59 & 0.95 & 4.40 \\
\hline Sphacelaria sp. & 0.52 & 0.93 & 2.45 & 1.08 & 4.17 \\
\hline Laurencia sp. & 0.48 & 0.89 & 2.41 & 1.16 & 4.09 \\
\hline Ceramium 5 & 0.50 & 0.00 & 2.21 & 0.96 & 3.75 \\
\hline Ceramium 2 & 0.40 & 0.00 & 2.05 & 0.95 & 3.48 \\
\hline Ceramium 4 & 0.58 & 0.23 & 2.01 & $1.60^{*}$ & 3.42 \\
\hline Enteromorpha prolifera & 0.48 & 0.19 & 1.97 & 1.29 & 3.35 \\
\hline Porphyra sp. & 0.35 & 0.01 & 1.71 & $2.49^{*}$ & 2.91 \\
\hline Cladophora 2 & 0.48 & 0.12 & 1.68 & $1.40^{*}$ & 2.85 \\
\hline Crouania 1 & 0.38 & 0.04 & 1.67 & 1.04 & 2.84 \\
\hline Polysiphonia 3 & 0.42 & 0.65 & 1.64 & $1.40^{*}$ & 2.79 \\
\hline Rivularia sp. & 0.00 & 0.32 & 1.60 & 0.94 & 2.71 \\
\hline Acrochaetium sp. & 0.27 & 0.43 & 1.59 & 1.37 & 2.69 \\
\hline \multicolumn{6}{|l|}{ May $1972(\bar{\delta}=65.54)$} \\
\hline Sphacelaria sp. & 0.34 & 0.85 & 3.42 & $1.44^{*}$ & 5.19 \\
\hline Porphyridium sp. & 0.43 & 0.01 & 2.99 & 0.86 & 4.54 \\
\hline Acrochaetium sp. & 0.78 & 0.31 & 2.82 & 1.75 & 4.28 \\
\hline Lichmophora sp. (diatom) & 0.49 & 0.00 & 2.82 & 0.96 & 4.28 \\
\hline Laurencia sp. & 0.32 & 0.56 & 2.63 & $1.76^{*}$ & 3.99 \\
\hline Enteromorpha intestinalis & 0.48 & 0.09 & 2.62 & 1.24 & 3.98 \\
\hline Enteromorpha (Ulva) lactuca & 0.39 & 0.00 & 2.55 & 0.93 & 3.88 \\
\hline Ceramium 4 & 0.32 & 0.39 & 2.35 & $1.89^{*}$ & 3.57 \\
\hline Polysiphonia 3 & 0.40 & 0.31 & 2.24 & 1.35 & 3.41 \\
\hline Ectocarpus rhizoclonium & 0.45 & 0.08 & 2.21 & $1.51^{*}$ & 3.35 \\
\hline Hypnea musciformis & 0.14 & 0.46 & 2.19 & $1.43^{*}$ & 3.32 \\
\hline Enteromorpha prolifera & 0.51 & 0.32 & 2.17 & $1.42^{*}$ & 3.29 \\
\hline Champia sp. & 0.28 & 0.38 & 1.91 & $1.61^{*}$ & 2.90 \\
\hline Cladophora 3 & 0.28 & 0.17 & 1.61 & 0.97 & 2.44 \\
\hline \multicolumn{6}{|l|}{ October $1972(\bar{\delta}=59.47)$} \\
\hline Ectocarpus rhizoclonium & 0.77 & 0.24 & 5.23 & $1.57^{*}$ & 8.53 \\
\hline Acrochaetium sp. & 0.47 & 0.12 & 3.86 & 1.31 & 6.29 \\
\hline Sphacelaria sp. & 0.58 & 0.87 & 3.52 & 1.13 & 5.75 \\
\hline Rivularia sp. & 0.38 & 0.19 & 3.39 & 1.02 & 5.53 \\
\hline Polycerea pylaiella & 0.41 & 0.30 & 3.26 & 1.27 & 5.33 \\
\hline Enteromorpha prolifera & 0.40 & 0.03 & 3.22 & 1.04 & 5.25 \\
\hline Ceramium puberulum & 0.12 & 0.38 & 3.14 & 1.15 & 5.13 \\
\hline Laurencia sp. & 0.18 & 0.34 & 2.81 & 1.18 & 4.58 \\
\hline Polysiphonia 3 & 0.20 & 0.16 & 2.03 & 0.96 & 3.32 \\
\hline Enteromorpha intestinalis & 0.24 & 0.03 & 2.03 & 0.71 & 3.31 \\
\hline
\end{tabular}



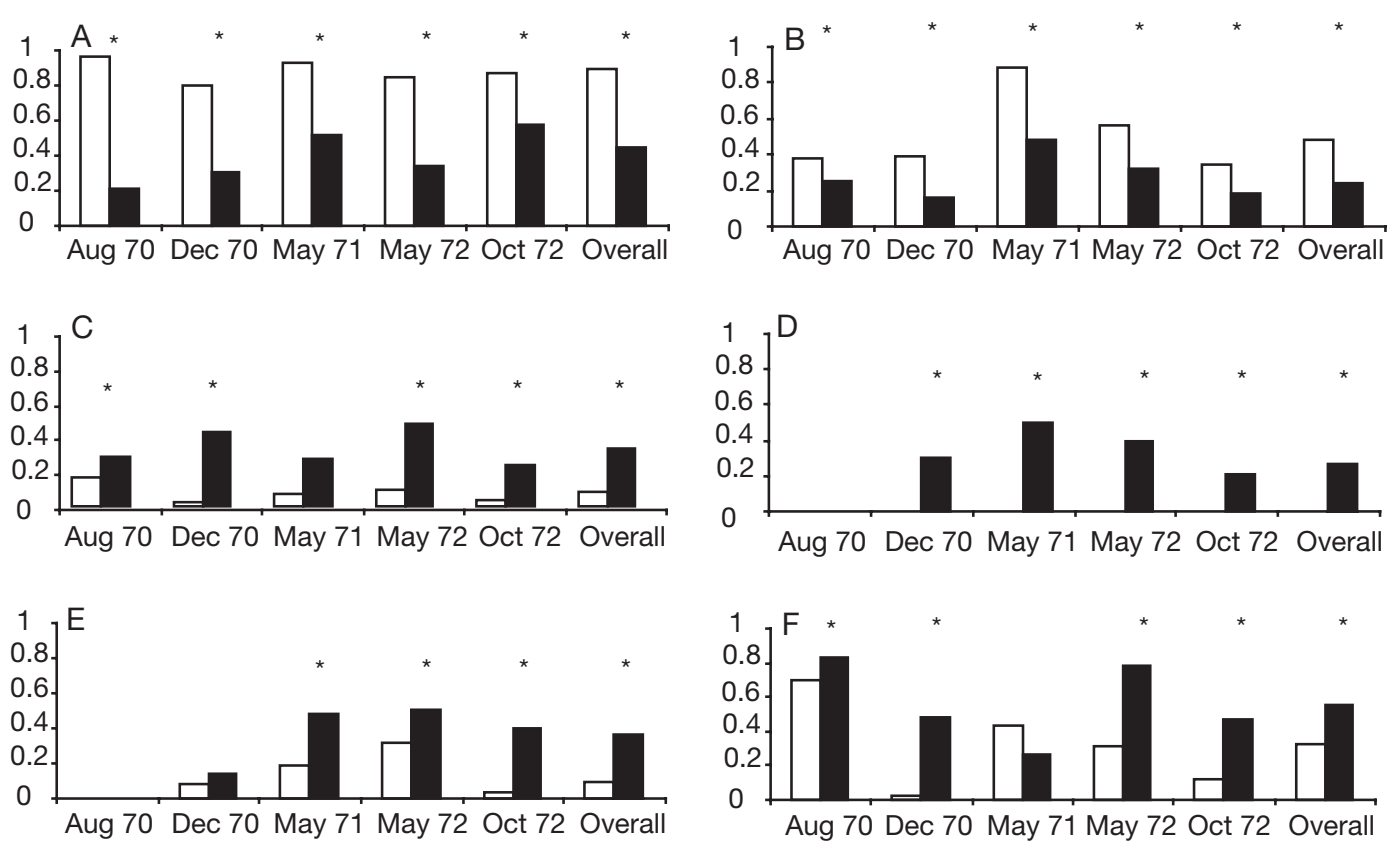

Fig. 4. Relative abundances of the 6 epiphyte taxa that were strong consistent contributors to dissimilarity on at least 3 of the 5 sampling occasions. ${ }^{*}$ : occasions when each species made $>3 \%$ contribution to dissimilarity (SIMPER analysis, Table 2 ) between No Loss (open bars) and Loss (filled bars) sites. A and B: species with higher abundance at No Loss sites, C and D: species with higher abundances at Loss sites. (A) Sphacelaria sp.; (B) Laurencia sp.; (C) Enteromorpha (Ulva) intestinalis; (D) Ulva lactuca;

(E) Enteromorpha prolifera; (F) Acrochaetium sp.

intestinalis, Enteromorpha (Ulva) lactuca, E. prolifera and Acrochaetium sp. (Fig. 4C-E) had higher average abundances at Loss sites and were absent or present in lower abundance at No Loss sites. The only exception to the trend was Acrochaetium sp., which had a higher average abundance at No Loss sites on a single sampling occasion in May 1971. E. lactuca, with the exception of a solitary blade in August 1970, was only present at Loss sites and was recorded on at least $20 \%$ and up to $50 \%$ of leaves sampled.

\section{Functional group analysis}

ANOSIM tests of functional group composition between No Loss and Loss sites showed low dissimilarity, in contrast to the clear differences at the species level (Fig. 2). Clarke's $R$ statistic was low overall (0.27), and for all sampling occasions (0.05 to 0.37$)$, and was not significant for 3 of the 5 sampling occasions.

The contrast in degree of dissimilarity at the species level compared to functional groups is attributed to changes in species compositions within single functional groups. For example, the filamentous brown alga Sphacelaria sp. was present with high abundances at No Loss sites, whereas another filamentous brown seaweed Ectocarpus sp. was abundant at Loss sites (Table 2). Two groups, however, showed consis- tent trends for 2 sampling occasions when there were weak significant differences in functional groups (May and October 1972), viz. foliose algae were more abundant at Loss sites (mostly the result of the prominence of species of Enteromorpha) and corticated filamentous algae were more abundant at No Loss sites (Tables $2 \& 3$ ).

\section{DISCUSSION}

This study aimed to determine whether shifts in species composition of epiphytic macroalgae occurred concurrently with seagrass loss, or whether changes in the epiphyte flora preceded the decline of the meadows. Changes in the epiphyte assemblage would provide a predictive indicator were they to occur before the demise of seagrass stands. Our analyses showed consistent differences in species composition of epiphytes over the 5 sampling occasions among sites where seagrass was lost and those where there was no loss. At the time of sampling, major loss of seagrass was in progress along the eastern shore of Cockburn Sound (Cambridge \& McComb 1984, Kendrick et al. 2002). At the scale and frequency of sampling, however, species shifts in epiphyte assemblages did not predict the loss of seagrass in advance of seagrass depletion. Later studies on short term changes in epi- 
Table 3. SIMPER analyses showing average relative abundances of functional groups of algal epiphytes at Loss and No Loss sites contributing to average Bray-Curtis dissimilarity $\bar{\delta}$ for those sampling occasions when ANOSIM analysis indicated a significant difference among Loss and No Loss sites. Groups are listed in order of their contribution to Bray-Curtis dissimilarity

\begin{tabular}{|c|c|c|c|c|c|c|}
\hline Functional group & $\begin{array}{l}\text { Avg. abundance } \\
\text { Loss sites }\end{array}$ & $\begin{array}{l}\text { Avg. abundance } \\
\text { No loss sites }\end{array}$ & Avg. dissimilarity & $\begin{array}{l}\text { Dissimilarity/ } \\
\text { SD }\end{array}$ & $\begin{array}{c}\text { Contribution } \\
\%\end{array}$ & $\begin{array}{c}\text { Cumulative } \\
\text { contribution \% }\end{array}$ \\
\hline \multicolumn{7}{|l|}{ May 1972} \\
\hline Foliose & 0.84 & 0.38 & 6.83 & 1.56 & 22.41 & 22.41 \\
\hline Corticate filamentous & 0.58 & 0.81 & 5.99 & 1.13 & 19.66 & 42.07 \\
\hline Saccate & 0.44 & 0.43 & 4.08 & 1.52 & 13.38 & 55.45 \\
\hline Blue green & 0.35 & 0.06 & 3.75 & 1.12 & 12.30 & 67.74 \\
\hline Encrusting & 0.78 & 1.00 & 3.55 & 0.53 & 11.65 & 79.39 \\
\hline Corticate foliose & 0.12 & 0.31 & 3.22 & 1.08 & 10.57 & 89.96 \\
\hline Articulated coralline & 0.13 & 0.11 & 2.19 & 0.94 & 7.20 & 97.16 \\
\hline Filamentous & 0.97 & 0.98 & 0.66 & 0.68 & 2.15 & 99.32 \\
\hline Leathery & 0.01 & 0.01 & 0.21 & 0.84 & 0.68 & 100 \\
\hline \multicolumn{7}{|l|}{ October 1972} \\
\hline Foliose & 0.69 & 0.09 & 8.38 & 1.81 & 28.10 & 28.10 \\
\hline Blue green & 0.47 & 0.32 & 6.15 & 1.26 & 20.63 & 48.73 \\
\hline Corticate filamentous & 0.48 & 0.71 & 4.89 & 1.50 & 16.39 & 65.12 \\
\hline Saccate & 0.14 & 0.31 & 3.43 & 1.34 & 11.51 & 76.63 \\
\hline Corticate foliose & 0.16 & 0.05 & 2.31 & 0.70 & 7.76 & 84.39 \\
\hline Filamentous & 0.95 & 0.92 & 1.77 & 0.64 & 5.94 & 90.33 \\
\hline Articulated coralline & 0.00 & 0.12 & 1.62 & 0.78 & 5.43 & 95.76 \\
\hline Encrusting & 0.93 & 0.99 & 1.26 & 0.38 & 4.24 & 100 \\
\hline Leathery & 0 & 0 & 0 & 0 & 0 & 100 \\
\hline
\end{tabular}

phytes provide an insight as to why changes in species composition may not necessarily predict seagrass losses more than a few months before gross changes become obvious. In a field study, seagrass (Posidonia sp.) from outside Cockburn Sound was transferred to a site near the nutrient source at James Pt. Within a few weeks, a predominantly encrusting calcareous epiphyte assemblage with low occurrence of larger individual macroalgae had changed to heavy epiphytic growths of filamentous brown and red algae (Ectocarpus rhizoclonium, Polysiphonia spp., Centroceras cinnabarinum) and foliose green algae (Ulva spp., Enteromorpha spp.). The host seagrass plants deteriorated over $10 \mathrm{wk}$, with overgrowth of the leaves by epiphytes (Cambridge et al. 1986). Thus, changes in epiphyte composition occurred within a few weeks and seagrass deteriorated in $<3$ mo.

In retrospect, we see that only one site at Rockingham Light (8) was sampled when seagrass showed no signs of deterioration and then on subsequent occasions as seagrass loss became evident in aerial photographs. At other Loss sites along the southeastern shore (9 to 13), sampling occurred when deterioration was already evident. Epiphyte composition at Rockingham Light became more similar to sites which had already lost seagrass but the degree of similarity varied over the sampling time, as shown by the different positions of RL on the nMDS plots in relation to other Loss and No Loss sites (Fig. 3). The lack of linear change may be a reflection of seasonally fluctuating conditions with differing hydrodynamic patterns (Mills \& D'Adamo 1995) which might have led to periods of improved or poorer conditions over $>2$ yr of sampling, until deterioration in the seagrass ecosystem became irreversible. The changes in epiphyte composition did not provide a warning signal which could be used as an indicator to enact preventative measures.

This study also provides detailed information on changes in epiphyte species in response to eutrophication by nitrogen loading in an oligotrophic, speciesrich environment. A few species proliferated in response to nutrient enrichment, often with different species occurring in different seasons, but with consistent presence of a few foliose species such as Ulva sp. Most species were rare and there was a natural spatial variation, suggesting a combination of seasonality and stochastic recruitment events. Epiphytes that formed a background of species consistently present at most sites (such as encrusting corallines and the filamentous brown alga Sphacelaria sp.) were present in lower abundances at the most eutrophicated sites. The separation of Loss and No Loss sites was driven largely by different taxa on each sampling date, and only 6 taxa contributed to dissimilarity on all 5 occasions, although $>100$ taxa were recorded during the study. Only 2 taxa were associated with No Loss sites consistently through all sampling times, i.e. Sphacelaria sp. and Laurencia sp. (Fig. 4). The other species contributing strongly to separation were foliose green seaweeds (Enteromorpha intestinalis, Enteromorpha prolifera, 
Ulva lactuca), which were abundant at Loss sites, but often still present in low abundance at No Loss sites. These are the only taxa which could be considered as potential indicator species for eutrophication and seagrass loss in this region. In studies from other regions, these species had characteristically fast growth rates, tending to overgrow or out-compete slower-growing foliose or encrusting species in nutrient-enriched conditions (Klavestad 1978, Neckles et al. 1994, Wear et al. 1999, Lin et al. 1996). Rapid overgrowth of Posidonia sp. leaves was attributed to increased nutrient availability in the usually oligotrophic temperate waters of southwestern Australia, but the role of a naturally low abundance or loss of mesograzers (Jernakoff et al. 1996, Jernakoff \& Nielsen 1997, 1998, Keuskamp 2003) in epiphyte proliferation, a mechanism proposed by Heck et al. (2000), has not been examined in this region.

Functional group analysis did not elucidate the subtle shifts in epiphyte assemblages so clearly shown by species analysis, although there were higher proportions of corticated filamentous algae at No Loss sites and foliose algae at Loss sites. In a species-rich environment, many changes in species are likely to have been withing single functional groups, resulting in considerable loss of information when considering functional form groups only, a finding similar to those of Phillips et al. (1997) who worked on shifts in algal community structure on reefs near our study area.

Previous studies of epiphytic algae in the region have demonstrated significant east-west differences in assemblage structure (Kendrick \& Burt 1997, Lavery \& Vanderklift 2002, Vanderklift \& Lavery 2000). In the present work, the east-west pattern in assemblages corresponded to differences in nutrient loading and effluent dispersal from a point source near James Pt in the eastern sector of Cockburn Sound. There is a strong association of known hydrodynamic and effluent dispersal patterns with the pattern of major loss of seagrass along the eastern shore from 1967 to 1981 (Fig. 5). Dispersal of effluent was constrained by wind and gyre circulation (Steedman \& Craig 1983). The influence of hydrodynamic conditions in retaining nutrient-enriched waters against the eastern shore before they were entrained in the central gyre occupying the northern half of the basin was evident from: (1) a tracer study in which cadmium, an inert component of effluent released south of James Point, showed a 'footprint' extending north and south from the point of its release (Rosman et al. 1980), and (2) from concentrations of water-column phosphate, with the highest values measured along the eastern shore and southeastern zone (Chiffings \& McComb 1981).

We conclude that superimposed over the natural spatial variation in assemblages in Cockburn Sound

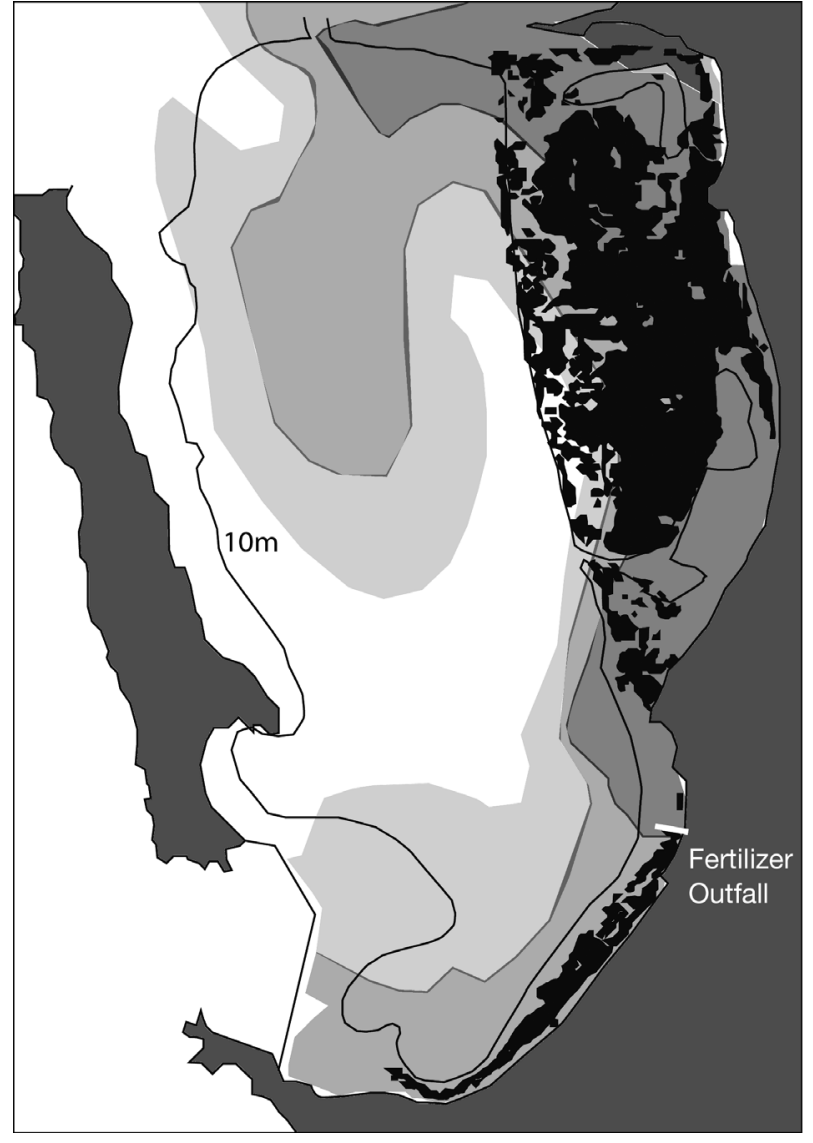

Fig. 5. Pattern of seagrass loss from 1967 to 1982 (black) along the eastern shore of Cockburn Sound superimposed over modelled dispersal of industrial effluent (shaded) released from south of James Point at the main source of N-loading for the eastern shore of Cockburn Sound (Fertilizer Outfall) during typical summer conditions. Relative cadmium concentrations (high, medium and low) in surface waters served as an inert tracer after a $10.5 \mathrm{~d}$ barotropic simulation forced by recorded winds, 18 to 28 December 1978 (after Rossman et al. 1980). Seagrass pattern adapted from Kendrick et al. (2002).

See Fig. 1 for geographic coordinates and sampling sites

the distribution of a suite of algae closely matched areas of seagrass dieback. At the scale and frequency of sampling, however, species shifts in epiphyte assemblages did not predict the loss of seagrass far enough in advance to allow sufficient time to take precautionary action. While this study showed that changes in algal assemblages correlated with seagrass loss, the natural variability, high species diversity and complexity of analysis preclude the use of individual indicator species as predictive indicators of seagrass loss. It is possible that with considerable additional sampling an 'indicator assemblage' might be identified. However, it is equally plausible that stochastic recruitment events dictate which species are present 
and able to respond to eutrophication events. The early observations of seagrass loss in Cockburn Sound (Cambridge et al. 1986) led to the conclusion that the losses were due to increase in biomass of epiphytes, but species shifts were also noted. This study confirms that differences in epiphyte assemblages correlated with seagrass loss, but we still lack detailed evidence of causal relationships, such as the role of optical properties of key species in reducing light transmittance, independently of, or in combination with, increases in epibiota biomass, or the role of epiphytes as competitors for carbon or nutrients at the leaf surface.

Acknowledgements. Field sampling was carried out by M.L.C. during a study by Environmental Resources of Australia Pty Ltd commissioned by the Fremantle Port Authority and Australian Commonwealth Department of Works. H. Womersley, E. Robertson and E. Wollaston (University of Adelaide) provided invaluable help with epiphytic algal identifications. We thank G. Kendrick and N. Goldberg for their helpful suggestions on the draft manuscript and the perceptive comments of an anonymous reviewer. M.L.C. was partially funded during writing by ARC Linkage Grant LP0454138.

\section{LITERATURE CITED}

Brun F, Vergara J, Navarro G, Hernandez I, Perez-Lorens J (2003) Effect of shading by Ulva rigida canopies on growth and carbon balance of the seagrass Zostera noltii. Mar Ecol Prog Ser 265:85-96

Brush MJ, Nixon SW (2002) Direct measurements of light attenuation by epiphytes on eelgrass (Zostera marina L.). Mar Ecol Prog Ser 238:73-79

Cambridge ML (1975) Seagrasses of south-western Australia, with special reference to the ecology of Posidonia australis Hook. f. in a polluted embayment. Aquat Bot 1:149-161

Cambridge ML, Kuo J (1979) Two new species of seagrasses from Australia, Posidonia sinuosa and P. angustifolia (Posidoniaceae). Aquat Bot 6:307-328

Cambridge ML, McComb AJ (1984) The loss of seagrass in Cockburn Sound. I. The time course and magnitude of seagrass decline in relation to industrial development. Aquat Bot 20:229-243

Cambridge ML, Chiffings AW, Britten C, Moore L, McComb AJ (1986) The loss of seagrass in Cockburn Sound. II. Possible causes and consequences. Aquat Bot 24:269-285

Cebrian JS, Enríquez S, Fortes M, Agawin N, Vermaat JE, Duarte CM (1999) Epiphyte accrual on Posidonia oceanica leaves: implications for light absorption. Bot Mar 42: $123-128$

Chiffings AW, McComb AJ (1981) Boundaries in phytoplankton populations. Proc Ecol Soc Aust 11:27-38

Clarke KR (1993) Non-parametric multivariate analyses of change in community structure. Aust J Ecol 18:117-143

Clarke KR, Warwick RM (2001) Changes in marine communities: an approach to statistical analysis and interpretation, 2nd edn. Primer-e, Plymouth

Coleman VL, Burkholder JM (1994) Community structure and productivity of epiphytic microalgae on eelgrass Zostera marina L. under water column nitrate enrichment. J Exp Mar Biol Ecol 179:29-48
Drake LA, Dobbs FC, Zimmerman RC (2003) Effects of epiphyte load on optical properties and photosynthetic potential of the seagrasses Thalassia testudinum Banks ex König and Zostera marina L. Limnol Oceanogr 48:456-463

Frankovich TA, Fourqurean JW (1997) Seagrass epiphyte loads along a nutrient availability gradient, Florida, USA. Mar Ecol Prog Ser 159:37-50

Frankovich TA, Zieman JC (2005) Periphyton light transmission relationships in Florida Bay and the Florida Keys, USA. Aquat Bot 83:14-30

Hauxwell J, Cebrian J, Furlong C, Valiela I (2001) Macroalgal canopies contribute to eelgrass (Zostera marina) decline in temperate estuarine ecosystems. Ecology 82:1007-1022

Heck KL, Pennock JR, Valentine JF, Coen LD, Sklenar SA (2000) Effects of nutrient enrichment and small predator density on seagrass ecosystems: an experimental assessment. Limnol Oceanogr 45:1041-1057

Jernakoff P, Nielsen J (1997) The relative importance of amphipod and gastropod grazers in Posidonia sinuosa meadows. Aquat Bot 56:183-302

Jernakoff P, Brearley A, Nielsen J (1996) Factors affecting grazer-epiphyte interactions in temperate seagrass meadows. Oceanogr Mar Biol Annu Rev 34:109-162

Kendrick GA, Burt JS (1997). Seasonal changes in epiphytic macro-algae assemblages between offshore exposed and inshore protected Posidonia sinuosa Cambridge et Kuo seagrass meadows, Western Australia. Bot Mar 40:77-85

Kendrick GA, Aylward MJ, Hegge BJ, Cambridge ML, Hillman K, Wyllie A, Lord DA (2002) Changes in seagrass coverage in Cockburn Sound, Western Australia between 1967 and 1999. Aquat Bot 73:75-87

Keuskamp D (2003). The role of epiphyte grazers in seagrass meadows in South Australia's Spencer Gulf. PhD thesis, Flinders University, Adelaide

Klavestad N (1978) The marine algae of the polluted inner part of the Oslofjord. A survey carried out 1962-1966. Bot Mar 21:71-97

Lavery PS, Vanderklift M (2002) A comparison of temporal and spatial patterns in epiphytic macroalgal assemblages of the seagrass Amphibolis griffithii and Posidonia coriacea. Mar Ecol Prog Ser 236:99-112

Lin HJ, Nixon SW, Taylor DI, Granger SL, Buckley BA (1996) Responses of epiphytes on eelgrass, Zostera marina L., to separate and combined nitrogen and phosphorus enrichment. Aquat Bot 52:243-258

Mills DA, D'Adamo N (1995) The application of a three dimensional baroclinic model to the hydrodynamics and transport of Cockburn Sound, Western Australia and surrounding waters. Technical Report Series, No. 76. Department of Environmental Protection, Perth, Western Australia

Moore KA, Wetzel RL (2000) Seasonal variations in eelgrass (Zostera marina L.) in response to nutrient enrichment and reduced light availability in experimental systems. J Exp Mar Biol Ecol 244:1-28

Neckles HA, Koepfler ET, Haas LW, Wetzel RL, Orth RJ (1994) Dynamics of epiphytic photoautotrophs and heterotrophs in Zostera marina (eelgrass) microcosms: responses to nutrient enrichment and grazing. Estuaries 17:595-605

Orth RJ, Moore KA (1983) Chesapeake Bay: an unprecedented decline in submerged aquatic vegetation. Science 222:51-53

Phillips JC, Kendrick GA, Lavery PS (1997) A test of the functional group approach to detecting shifts in macroalgal communities along a disturbance gradient. Mar Ecol Prog Ser 153:125-138

Rosman KJR, de Laeter JR, Chegwidden A (1980) The distrib- 
ution of cadmium in Cockburn Sound. Sci Total Environ 16:117-130

Silberstein K, Chiffings AW, Brittan C, Moore L, McComb AJ (1986) The loss of seagrass in Cockburn Sound, Western Australia. III. The effect of epiphytes on productivity of Posidonia australis Hook. f. Aquat Bot 24:355-371

Steedman RK, Craig PD (1983) Wind-driven circulation of Cockburn Sound. Aust J Mar Freshw Res 34:187-212

Steneck RS, Dethier MN (1994) A functional group approach to the structure of algal-dominated communities. Oikos 69:476-498

Editorial responsibility: Kenneth Heck (Contributing Editor), Dauphin Island, Alabama, USA
Tomasko DA, Lapointe BE (1991) Productivity and biomass of Thalassia testudinum as related to water column nutrient availability and epiphyte levels: field observations and experimental studies. Mar Ecol Prog Ser 75:9-17

Vanderklift MA, Lavery PS (2000) Patchiness in assemblages of epiphytic macroalgae on Posidonia coriacea at a hierarchy of spatial scales. Mar Ecol Prog Ser 192:127-135

Wear DJ, Sullivan MJ, Moore AD, Millie DF (1999) Effects of water-column enrichment on the production dynamics of three seagrass species and their epiphytic algae. Mar Ecol Prog Ser 179:201-213

Submitted: December 1, 2005; Accepted: March 8, 2006 Proofs received from author(s): September 10, 2007 